\title{
Front Matter: Volume 11737
}

, "Front Matter: Volume 11737," Proc. SPIE 11737, Advanced Optics for Imaging Applications: UV through LWIR VI, 1173701 (5 May 2021); doi: 10.1117/12.2598637

SPIE. Event: SPIE Defense + Commercial Sensing, 2021, Online Only 


\section{PROCEEDINGS OF SPIE}

\section{Advanced Optics for Imaging Applications: UV through LWIR VI}

Jay N. Vizgaitis

Peter L. Marasco

Jasbinder S. Sanghera

Editors

12-16 April 2021

Online Only, United States

Sponsored by

SPIE

Cosponsored by

optX Imaging Systems (United States)

Published by

SPIE 
The papers in this volume were part of the technical conference cited on the cover and title page. Papers were selected and subject to review by the editors and conference program committee. Some conference presentations may not be available for publication. Additional papers and presentation recordings may be available online in the SPIE Digital Library at SPIEDigitalLibrary.org.

The papers reflect the work and thoughts of the authors and are published herein as submitted. The publisher is not responsible for the validity of the information or for any outcomes resulting from reliance thereon.

Please use the following format to cite material from these proceedings:

Author(s), "Title of Paper," in Advanced Optics for Imaging Applications: UV through LWIR VI, edited by Jay N. Vizgaitis, Peter L. Marasco, Jasbinder S. Sanghera, Proc. of SPIE 11737, Seven-digit Article CID Number (DD/MM/YYYY); (DOI URL).

ISSN: 0277-786X

ISSN: 1996-756X (electronic)

ISBN: 9781510643116

ISBN: 9781510643123 (electronic)

Published by

SPIE

P.O. Box 10, Bellingham, Washington 98227-0010 USA

Telephone +1 3606763290 (Pacific Time)

SPIE.org

Copyright @ 2021 Society of Photo-Optical Instrumentation Engineers (SPIE).

Copying of material in this book for internal or personal use, or for the internal or personal use of specific clients, beyond the fair use provisions granted by the U.S. Copyright Law is authorized by SPIE subject to payment of fees. To obtain permission to use and share articles in this volume, visit Copyright Clearance Center at copyright.com. Other copying for republication, resale, advertising or promotion, or any form of systematic or multiple reproduction of any material in this book is prohibited except with permission in writing from the publisher.

Printed in the United States of America by Curran Associates, Inc., under license from SPIE.

Publication of record for individual papers is online in the SPIE Digital Library.

\section{SPIE. DIGITAL}

Paper Numbering: A unique citation identifier (CID) number is assigned to each article in the Proceedings of SPIE at the time of publication. Utilization of CIDs allows articles to be fully citable as soon as they are published online, and connects the same identifier to all online and print versions of the publication. SPIE uses a seven-digit CID article numbering system structured as follows:

- The first five digits correspond to the SPIE volume number.

- The last two digits indicate publication order within the volume using a Base 36 numbering system employing both numerals and letters. These two-number sets start with 00, 01, 02, 03, 04, 05, 06, 07, 08, 09, 0A, OB ... 0Z, followed by 10-1Z, 20-2Z, etc. The CID Number appears on each page of the manuscript. 


\section{Contents}

MATERIALS AND MANUFACTURING I

1173702 Simple optical characterization of new high index chalcogenide glass [11737-1]

1173705 Infrared optical material feedstocks [11737-4]

MATERIALS AND MANUFACTURING II

$1173708 \quad$ Review of molding machine technology for precision glass molding of chalcogenide glass [11737-7]

DESIGN AND APPLICATIONS

11737 OC Holographic optics for increased detection efficiency (Advanced Optics for Imaging Applications Best Student Paper Award) [11737-11]

POSTER SESSION

11737 OF Silicon-germanium alloy for infrared GRIN materials [11737-14] 
Proc. of SPIE Vol. 11737 1173701-4

\section{Downloaded From: https://www.spiedigitallibrary.org/conference-proceedings-of-spie on 26 Apr 2023
Terms of Use: https://www.spiedigitallibrary.org/terms-of-use}

